${ }^{4}$ Shabetai R, Fowler NO, Guntheroth WG. The hemodynamics of cardiac tamponade and constrictive pericarditis. Am 7 Cardiol 1970;26:480-9.

5 Reddy PS, Curtiss EI, O'Toole JD, Shaver JA. Cardiac tamponade: hemodynamic observation in man. Circulation $1978 ; 58: 265-72$.

${ }^{6}$ Feigenbaum H, Waldhausen JA, Hyde LP. Ultrasound diagnosis of pericardial effusion. $₹ A M A$ 1965;191:711-4.

7 Rubin RH, Moellering RC. Clinical, microbiologic and therapeutic aspects of purulent pericarditis. Am $\mathcal{f}$ Med 1975;59:68-78.

${ }^{8}$ Smolar EN, Rubin JE, Avramides A, Carter AC. Cardiac tamponade in primary myxedema and review of the literature. Am $\mathcal{F}$ Med Sci 1976; 272:345-52.

${ }^{9}$ Biran S, Brufman G, Klein E, Hochman A. The management of pericardial effusion in cancer patients. Chest $1977 ; 71: 182-6$.

10 Uhl GS, Koppes GM. Pericardial tamponade in systemic sclerosis (scleroderma). Br Heart f 1979;42:345-8.

11 McWhorter JE, Leroy EC. Pericardial disease in scleroderma (systemic sclerosis). Am F Med 1974;57:566-75.

12 Thadani U, Iveson JMI, Wright V. Cardiac tamponade, constrictive pericarditis and pericardial resection in rheumatoid arthritis. Medicine $1975 ; 54: 261-70$.

13 John JT, Hough A, Sergent JS. Pericardial disease in rheumatoid arthritis. Am 7 Med 1979;66:385-90.

14 Tew FT, Mantle JA, Russell RO, Rackley CE. Cardiac tamponade with nonhaemorrhagic pericardial fluid complicating Dressler's syndrome. Chest 1977;72:93-5.

15 Santos GH, Frater RWM. The subxiphoid approach in the treatment of pericardial effusion. Ann Thorac Surg 1977;23:467-70.

${ }^{16}$ Krikorian JG, Hancock EW. Pericardiocentesis. Am $\mathcal{F}$ Med 1978;65: 809-14.

\section{Eosinophilic fasciitis}

In the past six years at least $\mathbf{1 7}$ journals (including the $B M \mathcal{F}^{1}$ ) have published papers on what is variously called eosinophilic fasciitis or the Shulman syndrome, after the first case report ${ }^{2}$ in 1974.

The description of the syndrome has followed the classic pattern: firstly, a tentative report based on one or two cases; next, other isolated reports from many countries and many disciplines; and now the third stage, at which single centres (such as the Pittsburgh group, ${ }^{3}$ who first coined the term eosinophilic fasciitis), are able to give a detailed account of the pathological changes in 20 or more cases. ${ }^{4}$

Many clinicians see eosinophilic fasciitis as just a variant of scleroderma, while for others it is an entity. The characteristic feature is a widespread, often symmetrical sclerosis affecting especially the limbs but also the trunk. The fingers and face are usually, but not invariably, spared. Raynaud's phenomenon occurs only exceptionally, and most reports have described no systemic lesions apart from the carpal tunnel syndrome, which has been found in about one-third of cases. The sexes are equally affected. In up to half the cases the onset of symptoms seems to follow unaccustomed severe exercise. The characteristic pathological change is a thickening and inflammation of the deep fascia, best shown by a full-thickness biopsy specimen going through skin, subcutaneous tissue, and fascia, and into muscle. A distinctive feature of the syndrome is the presence of a blood eosinophilia, up to $4 \times 10^{9} / 1\left(4000 / \mathrm{mm}^{3}\right)$, though this may be transient, and tissue eosinophilia is unimpressive. There may also be hypergammaglobulinaemia.

The natural course of eosinophilic fasciitis is of a chronic disease, evolving over several months, but with a tendency then for spontaneous improvement, though contractures may persist. Response to treatment is difficult to assess in a disease with a definite but variable tendency. to regress, but corticosteroid drugs given by mouth over many months often seem to help-in contrast to their failure in most other types of scleroderma.
Scleroderma is often broadly subdivided into localised scleroderma or morphoea and progressive systemic sclerosis. It is too early to know whether eosinophilic fasciitis really is a definite "disease entity" or merely a variant of generalised morphoea, a well-recognised albeit ill-understood disease. ${ }^{56}$ In favour of its being a deep version of cutaneous scleroderma ${ }^{7} 8$ are the histological changes spreading up into the dermis, where they are indistinguishable from morphoea; the association in the same patient of typical eosinophilic fasciitis and typical plaques of morphoea; and the ability of linear morphoea to extend deeply through skin and into fascia, muscle, and even bone. Other types of scleroderma may also have blood eosinophilia. ${ }^{8-10}$

On the other hand, sclerosis of the skin and soft tissue occurs in many processes other than scleroderma and its variants. ${ }^{5}$ Until we know more of the pathological nature of this sclerosis there is much to be said for recognising eosinophilic fasciitis as a clinical syndrome but not being surprised that its delineation from other diseases is often blurred. The long controversy about the relation of morphoea and systemic sclerosis and the exact status of generalised morphoea suggests that similar arguments about the classification of eosinophilic fasciitis are likely to continue.

1 Stubbs SL, Hughes GRV. Eosinophilic fasciitis. Br Med $\mathcal{f}$ 1977;i:948-9.

2 Shulman LE. Diffuse fasciitis with hypergammaglobulinemia and eosinophilia: a new syndrome? f Rheumatol 1974;1: suppl:46.

3 Rodnan GP, di Bartolomeo AG, Medsger TA, Barnes EL. Eosinophilic fasciitis: Report of 7 cases of a newly recognized scleroderma-like syndrome. Arthritis Rheum 1975;18:422-3.

4 Barnes L, Rodnan GP, Medsger TA, Short D. Eosinophilic fasciitis: a pathologic study of twenty cases. Am f Pathol 1979;96:493-518.

5 Jablonska S. Scleroderma and pseudoscleroderma, 2nd ed. Warsaw: Polish Medical Publishers, 1975.

${ }^{6}$ Rowell, NR. In : Rook, AJ, Wilkinson DS, Ebling FJ, eds. Textbook of Dermatology, 3rd ed. Oxford: Blackwell, 1979.

${ }^{7}$ Caperton EM, Hathaway DE, Dehner LP. Morphea, fasciitis, and scleroderma with eosinophilia: a broad spectrum of disease. Arthritis Rheum 1976;19:792-3.

${ }^{8}$ Person JP, Daniel Su WP. Subcutaneous morphoea: a clinical study of sixteen cases. Br 7 Dermatol 1979;100:371-80.

- Fleischmajer R, Jacotot AB, Shore S, Binnick SA. Scleroderma, eosinophilia, and diffuse fasciitis. Arch Dermatol 1978;114:1320-5.

10 Don IJ, Khettry V, Canoso JJ. Progressive systemic sclerosis with eosinophilia and a fulminating course. Am $\mathcal{F}$ Med 1978;65:346-8.

\section{Viruses and winter vomiting disease}

Winter vomiting disease was first described 50 years $\mathrm{ago}^{1}$ by John Zoharsky in St Louis as an epidemic disease consisting of vomiting, colicky pain, and diarrhoea. Zoharsky recognised that it was not a true enteritis, but, despite recent advances in the diagnosis of acute intestinal viral infections, it can be difficult to differentiate from acute non-bacterial or juvenile gastroenteritis. Clinically, the main distinguishing features seem to be that winter vomiting disease is seen only in epidemics and that vomiting is more prominent than diarrhoea ${ }^{2}$ : children of school age are affected more often than the younger babies, in whom acute non-bacterial gastroenteritis is so prevalent. Nevertheless, the two diseases overlap. Virological investigation may not have much to offer in the management of an individual patient, but it is probably the only way to assess the part played by the numerous viruses which have been identified in the diseases.

Rotaviruses $^{3}$ are the main (though not the only) cause of acute non-bacterial gastroenteritis. ${ }^{4}$ The cause of winter 
vomiting disease is less clear. Various viruses have been implicated, mostly discovered by electron microscopy of stools. Unfortunately none of the candidate viruses grow in tissue culture and this has greatly hampered investigation of their pathogenicity. Nevertheless, techniques such as feeding the viruses to volunteers and immune electron microscopy have yielded much useful information. The main viruses found by these methods have been the Norwalk, ${ }^{5}$ Montgomery County, and Hawaii agents in the United States, ${ }^{6}$ and the W, ${ }^{7}$ Harlow, and Ditchling agents ${ }^{9}$ in Britain. By far the best studied of these is the Norwalk agent, but several general conclusions about all of them have emerged. The viruses are small (they are all about the same size ${ }^{9-11}$ ) and in most cases feeding them to volunteers reproduces alimentary symptoms. ${ }^{6}$ 7 11-13 Antibody is produced after both natural and experimental infections. ${ }^{101113}$ The relations between the viruses are confused. The Norwalk and Montgomery County agents are antigenically similar but differ from the Hawaii agent. ${ }^{11}$ The British W and Ditchling agents appear identical but they in turn differ from both Norwalk and Hawaii agents. ${ }^{6} 9$ Recently, another virus which appears identical with the Norwalk agent on electron microscopy has been reported in a hospital and community outbreak in Britain, though its antigenic relation to the Norwalk virus is unknown. ${ }^{14}$

Now a calicivirus has turned up as a cause of winter vomiting disease. $^{1516}$ Caliciviruses have a distinctive appearance ${ }^{17}$ and are best known as faecal viruses of such diverse species as sealions, pigs, and cats. ${ }^{18}$ The human variety was first reported by Madeley and Cosgrove ${ }^{19}$ but without any association with disease. Flewett and Davis confirmed finding calicivirus in human stools, but in this instance in two babies with gastroenteritis. ${ }^{20}$ Cubitt, McSwiggan, and Moore ${ }^{16}$ have now reported calicivirus associated with a typical outbreak of winter vomiting disease in a London school. The virus was present in the stools of seven of the 13 children affected. All the children developed antibody, though a teacher (the only adult affected) did not. Virus disappeared from the stools by the sixth day after onset and could not be found in the stools of healthy children in the school. This is convincing evidence that calicivirus caused the outbreak. Confirmation of the role of calicivirus in alimentary infections has also come from Japan, where Chiba and his colleagues $^{21}$ found it to be the cause of an outbreak of acute infectious diarrhoea in an infant's home. Here again the problem of differentiating winter vomiting from acute nonbacterial gastroenteritis becomes apparent.

Calicivirus is certainly not the only cause of winter vomiting disease, and in any event it may sometimes be present in the stools of babies without symptoms. ${ }^{22}$ The part played by the various viruses reported in both winter vomiting disease and acute non-bacterial gastroenteritis will be worked out only by thorough virological investigation of outbreaks, preferably notified at an early stage when specimens are available from patients with acute disease.

${ }^{1}$ Zahorsky J. Hyperemesis hiemis or the winter vomiting disease. Arch Pediatr $1929 ; 46: 391-5$.

2 Silverton Ml. An outbreak of illness at Rye Grammar School. Med Officer $1952 ; 88: 215$

${ }^{3}$ Bishop RF, Davidson GP, Holmes IH, Ruck BJ. Evidence for viral gastroenteritis. N Englf Med 1973;289:1096-7.

4 Flewett TH. Implications of recent virological researches. Ciba Foundation Symposium 1976;42:237-50.

${ }^{5}$ Adler JL, Zickl R. Winter vomiting disease. F Infect Dis 1969;119: 668-73.

${ }^{6}$ Wyatt RG, Dolin R, Blacklow NR, et al. Comparison of three agents of acute infectious nonbacterial gastroenteritis by cross-challenge in volunteers. F Infect Dis 1974; 129:709-14.
7 Clarke SKR, Cook GT, Egglestone SI, et al. A virus from epidemic vomiting disease. $\mathrm{Br} \mathrm{Med} \mathcal{F} 1972: \mathrm{iii}: 86-9$.

8 Appleton H, Higgins PG. Viruses and gastroenteritis in infants. Lancet $1975 ; \mathrm{i}: 1297$.

9 Appleton H, Buckley M, Thom BT, Cotton JL, Henderson S. Virus-like particles in winter vomiting disease. Lancet 1977; i:409-11.

${ }^{10}$ Kapikian AZ, Wyatt RG, Dolin R, Thornhill TS, Kalica AR, Chanock RM. Visualisation by immune electron microscopy of a $27-\mathrm{nm}$ particle associated with acute infectious nonbacterial gastroenteritis. $\mathcal{f}$ Virol 1972;10:1075-8.

11 Thornhill TS, Wyatt RG, Kalica AR, Dolin R, Chanock RM, Kapikian AZ. Detection by immune electron microscopy of 26 to $27 \mathrm{~nm}$ viruslike particles associated with two family outbreaks of gastroenteritis. $\mathcal{J}$ Infec Dis $1977: 135: 20-7$.

12 Dolin R, Blacklow NR, DuPont $\mathrm{H}$, et al. Transmission of acute infectious nonbacterial gastroenteritis to volunteers by oral administration of stool filtrates. F Infect Dis 1971:123:307-12.

${ }^{13}$ Dolin R, Levy AG, Wyatt RG, Thornhill TS, Gardner JD. Viral gastroenteritis induced by the Hawaii agent. Jejunal histopathology and serologic response. $A m \mathcal{F} M e d$ 1975; 59:761-8.

${ }^{14}$ Caul EO, Ashley C, Pether JVS. "Norwalk"-like particles in epidemic gastroenteritis in the UK. Lancet $1979 ; \mathrm{ii}: 1292$.

15 McSwiggan DA, Cubitt D, Moore W. Calicivirus associated with winter vomiting disease. Lancet $1978 ; \mathrm{i}: 1215$.

${ }^{16}$ Cubitt WD, McSwiggan DA, Moore W. Winter vomiting disease caused by calicivirus. $\mathcal{f}$ Clin Pathol $1979 ; 32: 786-93$.

${ }^{17}$ Madeley CR. Comparison of the features of astroviruses and caliciviruses seen in samples of feces by electron microscopy. F. Infect Dis 1979; 139:519-23.

${ }^{18}$ Andrews CH, Pereira HG, Wildy P. Viruses of vertebrates. 4th ed. London: Ballière Tindall, 1978;38-41.

19 Madeley CR, Cosgrove BP. Caliciviruses in man. Lancet 1976; i:199-200.

${ }^{20}$ Flewett TH, Davies H. Caliciviruses in man. Lancet 1976;i:311.

${ }^{21}$ Chiba S, Sakuma Y, Akihara $M$, Kogasaka R, Hoyino $K$, Nakao $T$. Stool viruses in babies in Glasgow 3. Community studies. In International Conference on Infant Nutrition and Diarrhoeal Disease. Kuala Lumpur, 1979.

${ }^{22}$ Scott TM, Madeley CR, Cosgrove BP, Stanfield JP. $f$ Hyg 1979;83: 469-85.

\section{Drugs and alcohol}

One elderly diabetic taking tolbutamide asked his doctor if he might have a drink to celebrate Christmas; he was told categorically that he must not. No doubt the harassed doctor, aware of the complex interactions between drugs and alcohol, ${ }^{1}$ must have thought a blanket prohibition the safest expedient.

A highly simplified view of the body's handling of alcohol may provide some guidance. Alcohol in social amounts increases gastric absorption, is freely distributed in the body water, and is eliminated in the liver by conversion to acetaldehyde with the aid of the cytosol enzyme alcohol dehydrogenase. Acute intoxication may induce pylorospasm, which will delay drug absorption. Furthermore, the alcohol will interact with microsomal enzymes responsible for drug metabolism, probably because they are brought into play to assist alcohol dehydrogenase in dealing with the excess or because stimulation of adrenocortical steroids inhibits microsomal enzymes. Repeated ingestion of alcohol (and cigarette smoking) leads to induction of drug-metabolising enzymes, so that the alcoholic may be less sensitive to drugs, provided that his liver is not seriously damaged.

In general, therefore, the acute effect of alcohol is to inhibit drug metabolism so that drug action is prolonged. In man this has been shown with phenylbutazone, phenobarbitone, meprobamate, and chloral hydrate. ${ }^{2} \mathrm{~A}$ similar action occurs with other barbiturates, opiates, and antipyrine after addition of alcohol in vitro and after its administration to animals. Diazepam has a strong synergistic action with alcohol, but with other benzodiazepines the action is weaker and they may be safer in certain circumstances. Anti- 